\title{
Strategic Planning Information System for Improving Quality of Datu Sanggul Hospital in Rantau
}

\author{
Kamarudin Hasan Basri $^{1}$, Erma Suryani ${ }^{1}$
}

\begin{abstract}
Datu Sanggul Hospital as one of the institutions engaged in health, has made information technology and information systems as part of business processes that accompany the business trip. Conditions that require unit Management Information System and Medical Record (SIM \& RM) to always accompany the institution to be not optimal when the blue print unit SIM \& RM service has not been integrated with other units in the planning.

This research will make SI / IT strategic plan needed by Datu Sanggul Hospital in Rantau for the current year 2018 to 2022. This research refers to the current condition of SI / TI and analyzed using several approaches to support the process of formulation of strategies that suit the needs.

This research was built using Ward \& Peppard method. The research step begins by using some analysis such as value chain, five forces, PEST until it can be mapped the position of hospital with SWOT analysis. The Datu Sanggul hospital position was in quadrant IV which applied strength-Threat strategy. Determination of future needs is done by using a balanced scorecard approach to find the appropriate Critical Success Factor needs. Until finally the formulation of the strategy of SI, IT, and IT management to form the portfolio of future applications in the form of 8 new applications, 1 application upgrade and 1 application replace, reliable human resources needed, build cloud computing and standardize governance with Cobit 4.1 and Documentation through ISO 9001: 2008 which is a support for blueprint service for SIM \& RM units for 2014 2018. The results of this strategic planning will provide direction to management for policy making involving investment, implementation and education required.
\end{abstract}

Keywords_-Datu Sanggul Hospital, Strategic IS/IT Planning, Analysis Value Chain, Analysis PEST, Analysiss SWOT.

\section{INTRODUCTION}

An organization especially a large organization should need to know where its advantages and disadvantages so that it can create effective strategies utilization of organizational resources that are owned in order to place themselves in the global business competition. Information and business systems that are not aligned can be seen from the utilization of information systems that have not been optimal in supporting the hospital business. In this case, planning an information system strategy is at stake to

\footnotetext{
${ }^{1}$ Kamarudin Hasan Basri, Erma Suryani are with Department of Information System, Faculty of Informatics Engineering, Institut Teknologi Sepuluh Nopember (ITS), Kampus ITS Sukolilo, Surabaya 60111, Indonesia. E-mail: kamarudin.skom@gmail.com; erma.suryani@gmail.com.
}

ensure that hospital information systems that support the achievement of organizational goals, so as to provide tangible results for the hospital [1].

Information systems in a large organization such as hospitals can provide information support to all levels of service administration with valid, accurate and complete data, and can be accessed easily, quickly and with wide reach of money. The hospital needs a strategic plan in order to be able to place itself in the right position in order to overcome the competition. With the plan of information system and information technology strategy (SI / IT strategy) to be able to apply and utilize organizational resources optimally, the development of SI / IT is purposeful and effective in achieving the desired target [2] In a hospital does not have a strategy plan of SI / IT resulted in the development of information system is not directed, the priority of development of IT / IT is not equal to business priority, there is no target and no stages in IT development, technology platform less directed to complicate the development of information system . The strategic plan is ideally done with a participatory approach where every staff of the SI / IT department is involved in the preparation. The SI / IT strategy will provide general guidance on building and developing future hospital information systems [3]. The SI / TI strategy is made with reference to current conditions and the dynamic conditions of the global environment [4]. Strategic design answers three questions: where is the current position of the organization, where and when it will achieve its goals, and how to achieve the goals [5]. User involvement, benefits, processes, support and leadership are the most important [6]. The IT / IT Strategy to be created should be aligned with the hospital strategy plan, which will be used by the hospital as a reference for the hospital management decision-making process in improving the quality of the hospital.

Hospital Accreditation Committee (KARS), see figure 1, developing the 2012 version of accreditation standards. This standard is more patient-focused; Strong in process, output and outcome; Strong on implementation and involving all officers in the process of accreditation. 


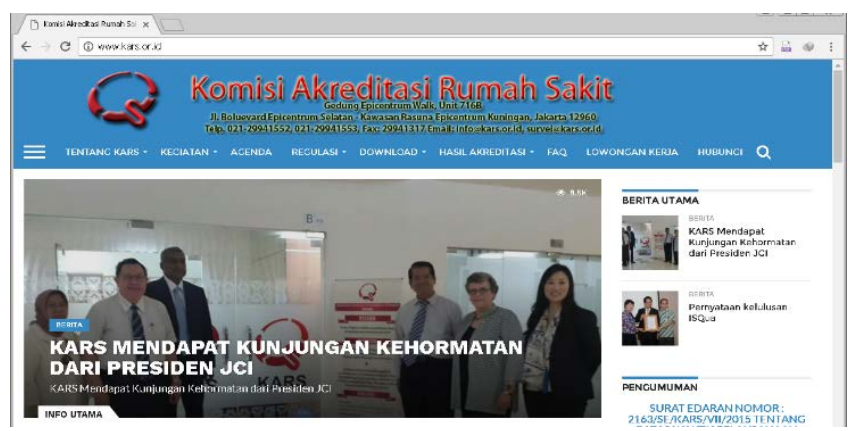

Figure 1. Hospital Accreditation Commission (KARS).

This improvement is expected that the hospital that passed the 2012 version of accreditation process can really improve the quality of its service with more focus on patient safety [7]. Based on the result of quality accreditation from KARS 2012, RSUD Datu Sanggul is at 1: 5 star rating with Pass status Prime, see Figure 2 below.

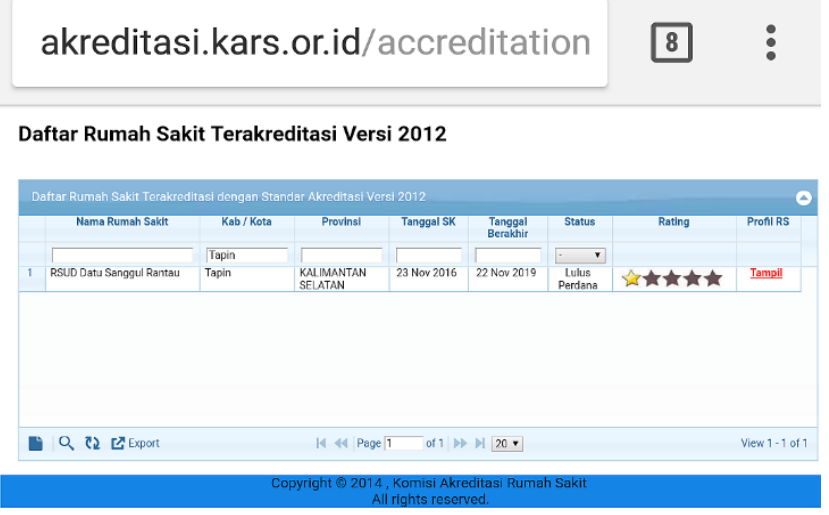

Figure 2. List of Accredited Hospital Versions 2012.

Various accreditation activities are implemented by Datu Sanggul hospital to improve hospital quality. Followed by several elements of hospital employees who are members of working groups (pokja), among them are nursing groups, medical record services and administrative services, working group emergency services. Documentation of working groups and activities that have been implemented in the framework of hospital quality accreditation can be seen in the appendix section.

In this 2012 accreditation standard there are 4 standard groups (Key Performance Indicator) consisting of 1,048 elements assessed. The four groups of hospital accreditation standards are: 1) patient-focused standard group, 2) group of hospital management standards, 3) patient hospital safety goals and 4) Millenium Development Goals [7].

Datu Sanggul Hospital has been using Hospital Management Information System (SIMRS) application. From this application all patient activities from registration process to pharmacy have been integrated, but until now there is no Standard Operating Procedure (SOP) and blueprint infrastructure or strategic plan of SI / IT in that hospital. Hospital information system goes without any clear reference so that the target and stages of IT development is less clear, whereas with the design strategy SI / IT all things related to information systems that run will be more focused and systematic that can be used by the organization For the development of information systems. In addition, the design of SI / IT strategy will make it easier for the management of the organization to make reference in the decision making process both internal and external related to the hospital.

\section{EXPERIMENTAL}

This research is done by using framework initiated by Ward and Peppard, by applying several process stages including introduction, understanding of current condition, interpretation of future requirement, strategy formulation.

\section{A. Introduction Phase}

This process is concerned with formulating the problem, purpose, and method of collecting the data taken. This research begins with some workmanship that is:

1. Make interviews and focus group discussions to determine the direction of the business.

2. Collect supporting data from company documents

3. Categorize survey results, and interviews

4. Mapping into codes to facilitate analysis.

5. The analyzes must be interrelated to facilitate the retrieval of the solution, identification, until the initial problem arises.

In the process of collecting data, researchers involve several parties to sharpen the understanding of existing business strategies and processes, with the hope of more clear strategies and business processes owned by Hospital Datu Sanggul will further sharpen the analysis results are also needed.

\section{B. Understanding of Current Conditionsi}

To understand the current conditions required analysis of four things as follows:

\section{1) Internal Business Analysis.}

There are two things that support them are:

a. Business strategy analysis - to see the company's view through the mission and strategy used to make it happen. Each of these findings is coded as a supporter of the analysis.

b. Value chain analysis - to see the existing activities and the advantages and disadvantages thereof, will be the findings to support the analysis.

\section{2) Internal IT Analysis}

To see existing conditions in internal IT, including analysis of infrastructure, human resources and skills encoded in "IT"

\section{3) External Business Analysis}

There are 2 things that become the supporting factors are:

a. PEST analysis - to see the factors that affect the business by looking at political, economic, social and technological factors, encoded with "PE".

b. Analysis of five forces - to see the factors that affect the business by looking at the competition encountered, encoded with "FF"

\section{4) External IT Analysis}

External IT analysis includes the use of information technology in the medical world that already exists today, encoded with "ET"

Of these four things will then be an input for the next analysis of the SWOT analysis to determine the current position of the company. 


\section{Value Chain Analysis}

Based on the organizational structure and main tasks that have been described, then the value chain analysis was developed to map in detail the existing activities at the Datu Sanggul hospital. After the mapping will be analyzed what positive value has been generated, what negative value should be evaluated, of course with the help of systems and information technology.

To describe the responsibility burden of each unit in carrying out its functions on 12 installation services it is necessary to find conformity by using RACI chart. It is used for decision making and assists management in identifying the roles and responsibilities of its employees. Clear division of tasks along with their roles and responsibilities are important in an organization. Unclear roles and responsibilities will cause confusion that will ultimately result in reduced productivity of its employees.

This collected activity will then be useful as input data on the information needed to determine what system, or what infrastructure can be added. The mapping into its value chain diagram can be seen in the picture below.

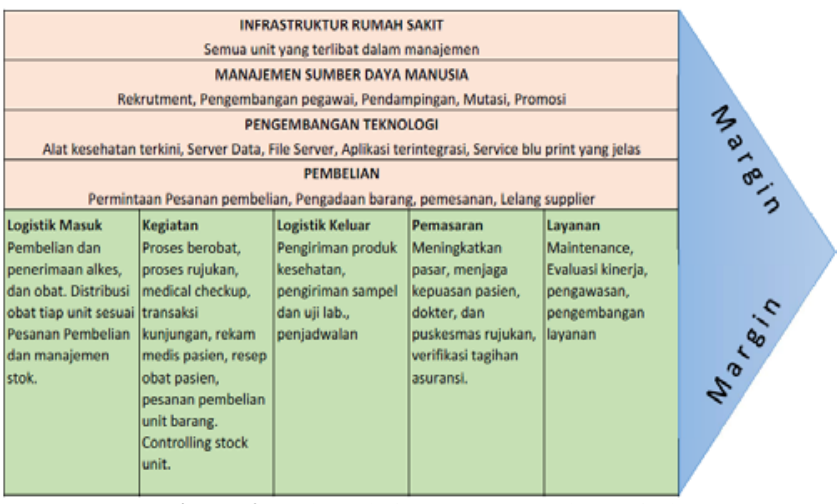

Figure 2. Value Chain Datu Sanggul Hospital

Activities that exist in the hospital body is divided into two activities, namely the main activity and supporting activities.

TABLE 1.

Result of Value Chain ANAlysis of Datu SANGgul Hospital

\begin{tabular}{|c|c|}
\hline Code & Analysis results \\
\hline $\mathrm{VCl}$ & Unorganized stock management \\
\hline VC2 & The purchase process through auction and direct appointment \\
\hline VC3 & The speed of medical records in the medical record update is less \\
\hline VC4 & Input medical record data that is often delayed by some units \\
\hline VC5 & $\begin{array}{l}\text { Not all parts of management use SIMRS even if it is installed } \\
\text { connected }\end{array}$ \\
\hline VC6 & Unit purchase order is appropriate \\
\hline $\mathrm{VC} 7$ & $\begin{array}{l}\text { Purchase order goods unit that is often late due to pending by the } \\
\text { vendor due to debts that the hospital is still in arrears }\end{array}$ \\
\hline VC8 & Unavailability of blueprint SI / IT hospitals \\
\hline VC9 & Integrated HRIS with no training \\
\hline VCl0 & Asset Management is less awake \\
\hline VCll & $\begin{array}{l}\text { Nurse competency care system has been implemented but less than } \\
\text { optimal }\end{array}$ \\
\hline
\end{tabular}

\section{PEST Analysis}

At this stage of the analysis will look for the factors that can affect the course of business in the political, economic, social and technological fields. The results of understanding on this analysis will facilitate in formulating the position of the hospital in the factors analyzed.

1) Political

Here are some political factors that affect the Datu Sanggul hospital:

- Regulation of the Minister of Health of the Republic of Indonesia on Hospital Information System.

- Government regulations on the Social Security Administering Body.

- Regent Regulation of Tapin.

2) Economy

The uncertain economic development is due to the many issues that hit Indonesia

- Currency dollar continues to affect the value of the rupiah currency.

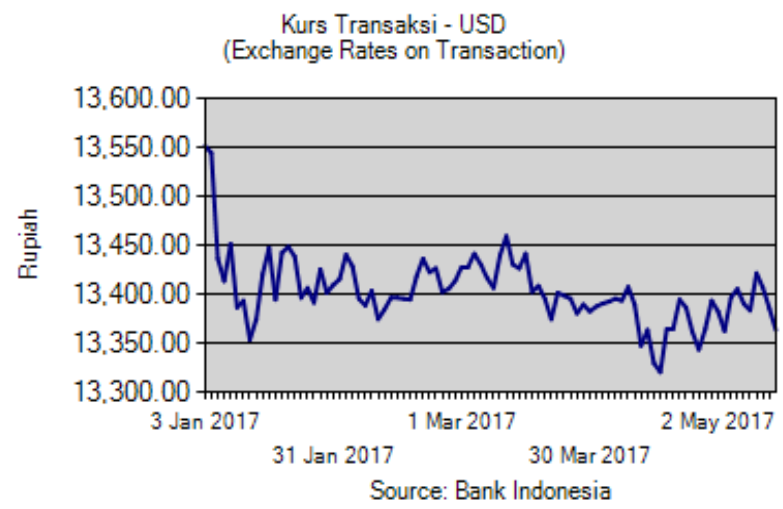

Figure 3. Exchange Rates on Transaction

- The increase in Regency Minimum Wage / Minimum Wage in 2017 affects the selling price of goods.

3) Social

In this social analysis more emphasized the position of hospital Datu Sanggul on social relations.

- Hospital of Datu Sanggul geographically located right in the heart of Rantau city.

- As population growth continues to increase, the population of Tapin district is 179,166 people.

- Hospital business of Datu Sanggul who continue to do business promotion at various events, including Tapin EXPO.

4) Technology

The various conveniences offered will be able to produce solutions for the medical world, depending on which perspective the technology will use.

- Use of Electronic Medical Record (EMR).

- Mobile Clinical Assistant (MCA).

- Utilization of Digital Image Processing.

- Budget issues and cost calculations on the utilization and use of technology.

- The problem of transfer of technology for users in the hospital, this becomes an obstacle for the development of technology in the hospital due to unwillingness of some users (doctors and nurses) using technology.

- The absence of blueprint technology. 


\section{E. Five Force Analysis}

In this five-force analysis aims to determine the position of the hospital on 5 elements of business competition. This analysis is very useful to know how far the influence of hospitals in the competition. Especially if the hospital wants to strengthen its position and identify the factors that make it work.

\section{1) Power of suppliers}

Suppliers that supply the Datu Sanggul hospital come from a variety of sources and models. Basically hospital of Datu Sanggul in determining the supplier of material needs done by auction system and direct appointment.

\section{2) Power of buyers}

The buyer here refers to the Datu Sanggul hospital patient. Patients from this hospital consist of:

- Patient BPJS

- Other Insurance Patients

- General patient

As comparison of patient visitation rate every year, it can be seen in the following table:

TABLE 2.

The Visit of DATU SANGgUl Hospital PATIENT

\begin{tabular}{|l|l|l|l|l|}
\hline \multirow{2}{*}{ NO } & \multirow{2}{*}{ VISIT } & \multicolumn{3}{|c|}{ YEAR } \\
\cline { 3 - 5 } & & \multicolumn{2}{|c|}{$\mathbf{2 0 1 4}$} & \multicolumn{1}{|c|}{$\mathbf{2 0 1 5}$} \\
\hline 1 & New pasien & 1925 & 1319 & 1599 \\
\hline 2 & Registered pasien & 1631 & 708 & 154 \\
\hline \multicolumn{2}{|c|}{ TOTAL } & $\mathbf{3 5 5 6}$ & $\mathbf{3 5 5 6}$ & $\mathbf{2 0 2 7}$ \\
\hline
\end{tabular}

Based on the data in the above table there is an increase in new patient visits compared to older patients (FF2), even in 2016 new patient visits 10x more than previous patient visits.

\section{3) Threat of substitutes}

The threat of replacement products has had a major impact on the hospitals business since the implementation of health BPJS regulation was implemented. It is said that every service served by BPJS must be started from the health center and family doctor as the frontline service window. This is a problem that is sufficiently seized the attention of the hospital because the strengthening of the promotion to refer patients to the hospital to the partners of hospitals such as health centers and family doctors should be strengthened.

\section{4) Threat of new entrants}

For competition from external fellow hospitals it can be said there is no competition, there is only a new maternity clinic that stands to be a competitor around the coverage area of the Datu Sanggul hospital.

\section{5) Rivalry among competition}

Datu Sanggul Hospital is the first and oldest hospital in Rantau city. Until now there is no other hospital standing nearby in the same city.

\section{F. Strategic Grid Analysis}

In this strategic grid analysis will be discussed the current portfolio of applications that will be mapped in the strategic grid. Where the usefulness of this strategic grid to see how far the position of running applications.
TABLE 3. STRATEGIC GRID APPLICATION MAPPING

\begin{tabular}{|l|l|}
\hline \multicolumn{1}{|c|}{ STRATEGIC } & \multicolumn{1}{|c|}{ HIGH POTENTIAL } \\
\hline $\begin{array}{l}\text { Executive module } \\
\text { Human resource information system } \\
\text { Clinical Pathway } \\
\text { Income }\end{array}$ & \\
\hline \multicolumn{1}{|c|}{ KEY OPERATIONAL } & \multicolumn{1}{c|}{ SUPPORT } \\
\hline $\begin{array}{l}\text { Inpatient module } \\
\text { Outpatient module }\end{array}$ & Laboratory module \\
Medical record module & Radiology module \\
$\begin{array}{l}\text { Pharmacy module } \\
\text { Payment module }\end{array}$ & Operating room module \\
Poly module & Service module \\
Medical record module & Medical / non medical support \\
Nutrition module & Food Patients \\
The pantry module & Absence \\
Nursing module & Queue front office, pharmacy, \\
Warehouse module & specialist \\
Logistics module & Schedule is OK \\
Bridging insurance & Physical production \\
Salary Doctor & Inventory Value \\
Debts and receivables & Library \\
Census & Helpdesk \\
A TK & \\
Warehouse inventory & \\
Financial module & \\
Cafe & \\
Expedition & \\
IGD Module & \\
\hline
\end{tabular}

\section{G. Analysis of External Environment IS/IT}

In this analysis of the external environment will be discussed what are the trends of technology that exist in the business world. And some that can be used to support the process of diagnosis, recording and convenience for the medical world.

\section{1) IT Trends}

The rapid development of the IT world demands anyone, especially the business world to get in touch with it. This is more because the world of information technology is likened to the heart of the rotation of information, so that every step generated by technology is believed to bring acceleration. The technology that develops in the world of information technology is:

\section{a. Cloud Computing}

This technology is a technology that uses the internet and server networks provided by service providers to manage data and applications. Services offered by cloud computing are quite diverse, for example, by utilizing Software as a Service (SaaS) can enable organizations to install online and Infrastructure as a Service (IaaS) to save on server investment and server maintenance costs

b. Mobile

Applications built with the mobile concept are in great demand until many organizations are applying the use of this technology to their business processes. With a relatively inexpensive infrastructure and relying on the network infrastructure owned by today's providers underlies the number of these applications developed. Especially when so many gadgets that dominate the telecommunications technology market increasingly pave the way for mobile applications.

\section{2) IT Trends in Medical}

The world of identical medicine is accompanied by technology that simplifies it. The higher science of developing medicine commonly juxtaposed with the development of technology that is the trend. So that so 
many technologies are attached to the world of medicine and can be a tool that gives more benefits and is seen as effective and even efficient. Some of the technologies used in the medical world are as follows:

\section{a. Usage Electronic Medical Record (EMR)}

As passed in law No. 11 of 2008 on electronic information and transactions, it will be the right solution to the limitations of land and storage, the security of access rights can also be arranged in such a way that with other technologies such as telemedicine, Home, or anywhere else can use the technology to make the diagnosis while not in place.

b. Mobile Clinical Assistant (MCA)

In line with the above EMR will be able to facilitate the doctor who handles the patient while in hospital, or when at home though. Information stored on the basis of physician and patient-only IDs leads doctors to see details, study their patients in more detail.

\section{c. Utilization of Digital Image Processing}

The use of this technology in such a way coupled with telemedicine will be able to present the digital sensing system of ultrasound, CT-Scan or MRI from remote.

\section{3) SWOT Mapping}

After understanding the current hospital conditions, the position of the hospital mapped into SWOT analysis to find the side of strenghts, weakness, opportunities, and threats based on the key success factors obtained from the previous analysis.

From the analysis that has been made can be calculated the difference between strength and weakness, opportunities and threats. This can be mapped into the SWOT coordinate mapping to determine the position of the Datu Sanggul hospital. The results of the mapping can be seen in the picture below.

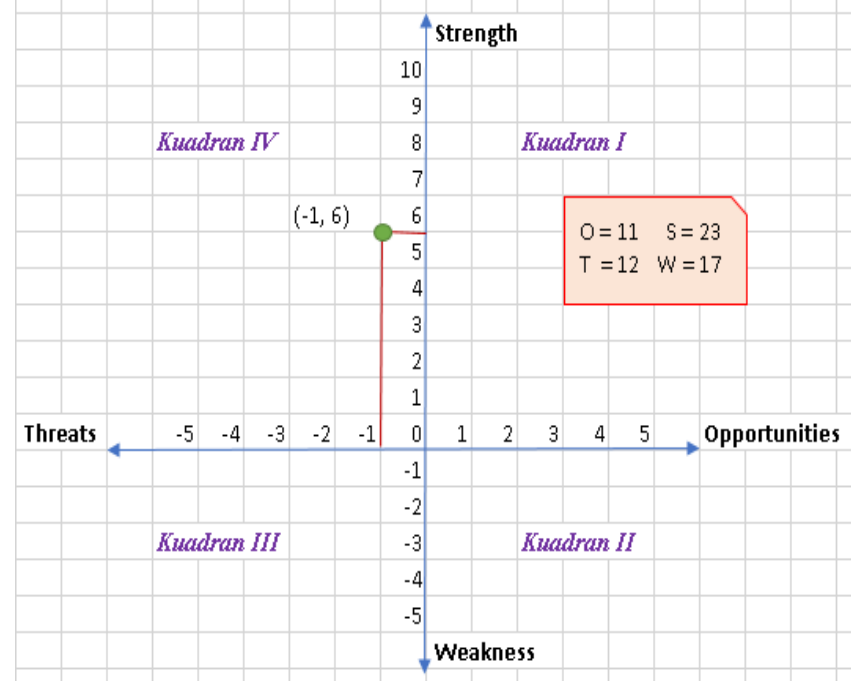

Figure 3. Position of Datu Sanggul Hospital on SWOT Mapping

After mapping, the image can be seen in the position of Datu Sanggul hospital located in quadrant IV at the coordinate point $(-1,6)$, which means the strategy is focused on Strength-Threat strategy (ST), that is by focusing the strategy on maximizing the owned empowerment To minimize the threats that come to achieve success in improving the quality of the hospital.

\section{1) Mapping Strategic Strength-Threat to Balance Scorecard}

The strategy used is divided into 4 aspects, namely financial aspects, customer aspects, internal business process aspects, and aspects of learning and growth. From these four aspects emerged strategic objectives that resulted in a strategy to make it happen.

In the Balance Scorecard there is a strategic map to illustrate the process flow of strategies implemented by the hospital. The strategy to be achieved is a strategy to achieve financial supported by the customer (patient), internal business processes and aspects of learning and growth. In the following table can be sorted out what strategies are used.

2) Combination of Balance Scorecard Analysis to Critical Success Factor

The results of the balanced scorecard are then combined with critical success factors analysis to provide a more comprehensive information system needs. The steps taken for the analysis of critical success factors are as follows:

a. Identification of business objectives in this case describes the mapping of business needs, benchmarks and Strength-Threat strategies used.

b. Obtain the necessary data and information as part of the proper preparation of critical success factors.

c. Description of activities to realize the solution to the necessary improvement efforts of the critical success factor, as well as to realize the size of the results that have been declared.

The following is an example of CSF analysis for business needs, the ability of hospitals to increase revenue and efficiency

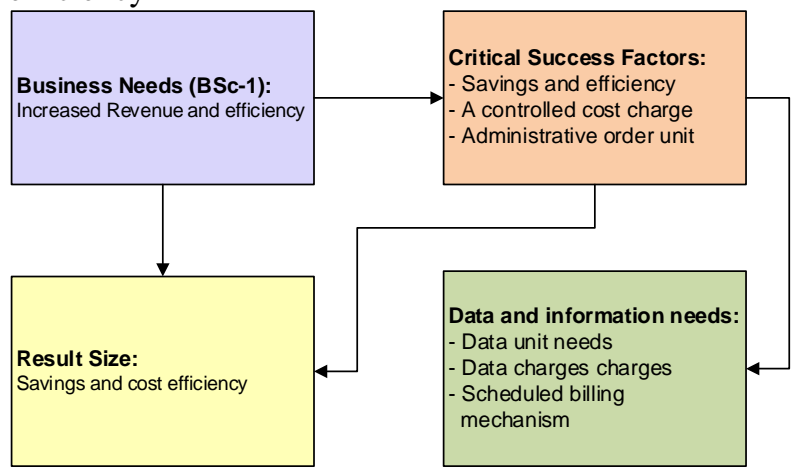

Figure 4. CSF analysis for business needs, the ability of hospitals to increase revenue and efficiency

Activities include:

- Creating an Accounting Information System application with a cost module

- Creating asset management with an early warning system module for each unit of finance

- Create a payment scheduling module

\section{RESULTS AND DISCUSSION}

Various analyzes have been conducted to determine the planning according to the needs of the Datu Sanggul hospital, which is used as a tool to detect any possibilities that can support the strategy. Beginning with the interpretation of current needs that can map the factors of strength, weakness, opportunities and threats encountered. 
Alignment with the accuracy of business needs is also done to map precisely the needs of the hospital on the implementation of a technology, so in line with business needs. The next step is to formulate IS / IT strategy planning that is divided into IS business strategy, IT strategy and IS / IT management strategy. Next is a recommendation given on the IS / IT strategy planning formulation at Datu Batur hospital.

\section{A. Recommended IS Business Strategy}

The purpose of SI's business strategy recommendation is how each unit can utilize SI / IT in achieving business goals. Critical success factors that have been obtained in the previous discussion, mapped in accordance with potential business needs of information system needs.

After knowing the need of information system for Datu Sanggul hospital, then arranged roadmap planning of information system development needed based on priority scale and planned during period 2018-2022. The priority scale made is expected to be able to know which needs should be precedence and which needs to be postponed, thus meeting the needs that are not appropriate and tend to Sanggul hospital influenced several factors that include; 1) income level, 2) social status, 3) social environment. While in the process of preparing the priority scale by considering the following considerations; A) the level of urgency, b) opportunities owned, c) future considerations, and d) selfability.

TABLE 4.

PRIORITY SCALE IS BUSINESS STRATEGY

\begin{tabular}{|l|l|l|}
\hline \multicolumn{1}{|c|}{ Urgent } & \multicolumn{1}{c|}{ Less urgent } \\
\hline important & Telemedicine & $\begin{array}{l}\text { Executive information } \\
\text { system } \\
\text { Customer relationship } \\
\text { management } \\
\text { Application quality } \\
\text { indicators }\end{array}$ \\
\hline not too important & $\begin{array}{l}\text { Asset management } \\
\text { Management } \\
\text { cooperation } \\
\text { HRIS }\end{array}$ & $\begin{array}{l}\text { Accounting information } \\
\text { system } \\
\text { SIMRS } \\
\text { e-Procurement }\end{array}$ \\
\hline
\end{tabular}

\section{B. Recommended Information Technology Strategy}

To support the decision of the business strategy of information systems, there are several recommendations related to IT strategy, namely:

\section{1) Construction of data center (KTI 1)}

Establish an appropriate data center of ANSI / TIA-942 (Telecommunications Industry Association) standard that enables Datu Sanggul hospitals to conduct business processes and transactions safely and standards in accordance with IT governance rules.

\section{2) Cloud Computing (KTI 3)}

To support the information system strategy in the form of telemedicine, this technology is needed as a medium to facilitate make it happen.

\section{3) Disaster Recovery Plan (KTI 4)}

The importance of protecting the data in the cloud system, and the transactional data needed to be reinforced by planning for disasters. This is a form of prevention for the occurrence of undesirable things.
4) Recommendations for human resource development (KTI 2)

Development and improvement of human resources of information technology is needed to gain IT maturity as business enabler.

Here are some training recommendations related to the development and improvement of human resources of information technology:

- IT Project Management

- IT Audit \& IT Security

- IT Government

- Helpdesk Management

- Web Application

- IT Policy

C. Recommended Information Technology Management Strategy

Recommendations given to information technology management are as follows:

- Information technology governance as per COBIT 4.1 (MTI 1)

- ISO 9001: 2008 Certificate (MTI 2)

As with SI's business strategy, the scale of projection is also used for mapping IT strategy and IT Management. Here is a priority scale.

TABLE 5.

PRIORITY SCALE IT STRATEGY AND IT MANAGEMENT IN HOSPITAL

\begin{tabular}{|c|c|c|}
\hline & Urgent & Less urgent \\
\hline Important & $\begin{array}{l}\text { Data center according to } \\
\text { ANSI / TIA } 942 \text { standard }\end{array}$ & $\begin{array}{l}\text { Cloud computing } \\
\text { Disaster recovery plan }\end{array}$ \\
\hline Not too important & $\begin{array}{l}\text { Training IT project } \\
\text { management } \\
\text { Training IT government } \\
\text { Training IT audit \& } \\
\text { security } \\
\text { Training IT policy }\end{array}$ & $\begin{array}{l}\text { IT governance as per } \\
\text { COBIT standard } 4.1 \\
\text { ISO 9001: } 2008 \text { certificate } \\
\text { Training r helpdesk } \\
\text { management }\end{array}$ \\
\hline
\end{tabular}

Here is a mapping of Information Technology and Information Technology Management strategy.

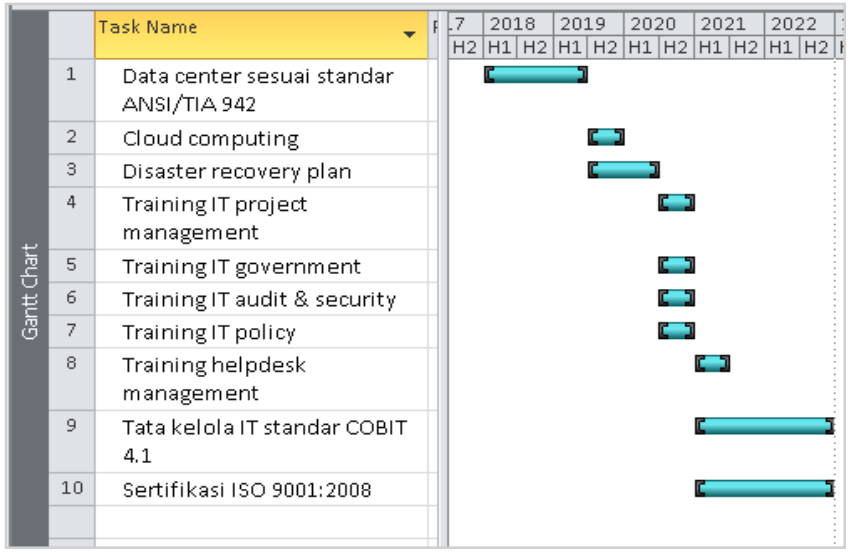

Figure 5. Mapping Information Technology Strategy and Information Technology Management

\section{Future Application Portfolio}

Based on the results of the previous analysis, the future application portfolio can be seen in the grid strategy below. 
TABLE 5. STRATEGIC GRID OF FUTURE PORTFOLIO

\begin{tabular}{|l|l|}
\hline \multicolumn{1}{|c|}{ STRATEGIC } & \multicolumn{1}{c|}{ HIGH POTENTIAL } \\
\hline $\begin{array}{l}\text { Executif Information System } \\
\text { Customer relationship management } \\
\text { Application quality indicators }\end{array}$ & Telemedicine \\
\hline \multicolumn{1}{|c|}{ KEY OPERATIONAL } & \multicolumn{1}{c|}{ SUPPORT } \\
\hline $\begin{array}{l}\text { Accountant information system * } \\
\text { SIMRS * } \\
\text { e-Procurement }\end{array}$ & $\begin{array}{l}\text { Asset management } \\
\text { Management cooperation }\end{array}$ \\
\hline
\end{tabular}

Information:

*Current app that needs to be refined. In addition is the recommended application to support the strategy of SI / IT.

\section{ACKNOWLEDGEMENT}

This work is supported by Tapin District Health Office, Rantau City, South Kalimantan in Indonesia.

\section{REFERENCES}

[1] P. Rahardjanto, "Pengembangan Pelayanan Rumah Sakit Umum Daerah Tugurejo - Semarang,” Universitas Diponegoro, 2008.

[2] Subli, "Rencana strategis sistem informasi :: Studi kasus RSUD Dr. M. Yunus Bengkulu,” Universitas Gadjah Mada, 2008.

[3] B. Brigl et al., "Preparing strategic information management plans for hospitals: a practical guideline," Int. J. Med. Inform., vol. 74, no. 1, pp. 51-65, Jan. 2005.

[4] KOMINFO, Rencana Strategis Kementrian Komunikasi dan Informatika 2010-2014. Jakarta: KOMINFO, 2010.

[5] M. Allison, Perencanaan strategis bagi organisasi nirlaba: pedoman praktis dan buku kerja / Michael Allison dan Jude Kaye. Jakarta: Yayasan Obor Indonesia, 2005.

[6] K. Cresswell and A. Sheikh, "Organizational issues in the implementation and adoption of health information technology innovations: An interpretative review,” Int. J. Med. Inform., vol. 82, no. 5, pp. e73-e86, May 2013.

[7] P. A. Rahma, "Akreditasi Rumah Sakit, Pengakuan Atas Kualitas Layanan,” Majalah Dental\&Dental, 2012. 